\title{
SYSTEMATIZING A CULTURE OF PEACE IN THE SANTA TERESITA DEL VALLE SCHOOL, QUITO - ECUADOR
}

\section{SISTEMATIZAR LA CULTURA DE PAZ EN LA ESCUELA SANTA TERESITA DEL VALLE, QUITO - ECUADOR.}

MILICA DRAGOSAVLJEVICH ${ }^{1}$

MARITZA FIGUEROA P. ${ }^{2}$

Recibido: 30 de mayo de 2018

Aceptado: 22 de octubre de 2018

\footnotetext{
${ }^{1}$ Pontificia Universidad Católica del Ecuador, Facultad de Comunicación, Lingüista y Literatura, Quito, Ecuador, Mfigueroa818@puce.edu.ec

${ }^{2}$ Pontificia Universidad Católica del Ecuador, Facultad de Comunicación, Lingüista y Literatura, Quito, Ecuador, mdragosav@puce.edu.ec
} 



\section{SYSTEMATIZING A CULTURE OF PEACE IN THE SANTA TERESITA DEL VALLE SCHOOL, QUITO - ECUADOR}

\section{SISTEMATIZAR LA CULTURA DE PAZ EN LA ESCUELA SANTA TERESITA DEL VALLE, QUITO - ECUADOR.}

Milica Dragosavljevich, Maritza Figueroa P.

Keywords: Culture of peace, Peace Education, Community development, research methods

Palabras Clave: Cultura de paz, educación para la paz, desarrollo comunitario, método de investigación

\section{RESUMEN}

Este artículo describe los resultados del análisis y la evaluación de la implementación de la educación para una cultura la paz en la escuela primaria Santa Teresita del Valle en Quito - Ecua- dor. Los procesos de educación para una cultura de la paz fueron facilitados por estudiantes y profesores de la Pontificia Universidad Católica del Ecuador (PUCE), particularmente de las Escuelas de Traba- 
jo Social y Multilingüe de Negocios Internacionales y Relaciones Internacionales quienes en conjunto formaron parte de uno de los proyectos de responsabilidad social universitaria de la PUCE. Se utilizó la Metodología de Sistematización de Experiencias para investigar cómo los talleres de cultura de la paz afectaron a los actores sociales de la Escuela Santa Teresita del Valle durante el año 2016. Durante este proceso, el Consejo de la Judicatura exigió que las escuelas públicas de Quito apliquen su programa "Semilleros de Convicencia" (talleres de coexistencia pacífica), basado en los preceptos de Cultura de Paz y el modelo pedagógico crítico de David Kolb y Paulo Freire. De esta manera, se desarrolló un proyecto que no solo incluyó los requerimientos del órgano estatal, sino los conocimientos y mística de la Escuela Multilingüe de Negocios y la de Trabajo Social, como programas educativos bajo el paradigma de la Pedagogía Ignaciana. Se resalta el trabajo en equipo entre dos Escuelas de la PUCE como la interinstitucionalidad con el Consejo de la Judicatura del Ecuador y las Unidades Educativas de Fe y Alegría.

\section{ABSTRACT}

This paper describes the main outcomes from analyzing and evaluating the implementation of culture of peace education at the Santa Teresita del Valle School, a primary school located in Quito, Ecuador. The culture of peace education was facilitated by students and adjunct professors of the Pontifical Catholic University of Ecuador (PUCE), from the Multilingual School of International Business and International Relations (MSIBIR) and the School of Social Work, who engaged in community outreach programs. Systematization of Experience Methodology, that encompasses different research methods, was used to investigate and question how culture of peace workshops impacted Santa Teresita del Valle School stakeholders over a period of one year. During this process, the Ecuadorian Judicial Council had required public schools in Quito to apply their "Semilleros de Conviviencia" (Planting Peaceful Co-Existence Workshops), program based on the precepts of Culture of Peace and David Kolb and Paolo Freire's critical pedagogical model. The Santa Teresita del Valle School, in turn, requested that PUCE act as a facilitator for the workshops. This petition was adhered to by the PUCE's Outreach Department, and a project was developed using the logical framework approach and the existing agreement between 
both ally institutions. The project included not only the Ecuadorian Judicial Council's petition, but also consisted of the creation of an entire program that integrated the MSIBIR and the School of Social Work's know-how and mystique as educational programs under the lgna- tian Pedagogy Paradigm. The Culture of Peace Workshops for Santa Teresita del Valle were thus developed, implemented and consequently evaluated pursuant the principles of Systematization of the Experience Methodology.

\section{INTRODUCTION}

Through its Ignatian Pedagogical Paradigm, the Pontifical Catholic University of Ecuador (PUCE) strives to "educate persons who are socially engaged in the pursuit of peace, development and human dignity" (PUCE, 2016, pg. 2). The University supports projects to promote social justice and a culture of peace, thus the Culture of Peace project in Santa Teresita is included under this Ignatian Paradigm.

The project at hand grew out of the necessity to promote a space for peace solidarity, both at school and home, in order to enhance the quality of education for children. It is important to point out that, since both school and home are influential in children's' education, it is fundamental that these spaces be integrated when speaking of building peace in the minds of children and their immediate surroundings.

Building a Culture of Peace requires the integration of assertive communication, which in turn calls for active listening and, above all, an inner search for the solution to our problems.

The methodology used to analyze and evaluate how culture of peace education is applied and promoted is called Systematization of Experiences. It was first introduced by Oscar Jara (2012), a prominent sociologist and educator from Costa Rica. This methodology allows researchers to have a detailed organizational framework which enables posterior examination and scrutiny of experiences.

The PUCE's outreach program uses the logical framework approach to create outreach community programs in accordance with its mission and vision as a Jesuit University. Therefore, a year-long study was conducted to apply Culture of Peace Education in a primary school setting (the Santa Teresita del Valle School) to later be evaluated through the lens of Systematization of Experiences methodology. 
The methodology employed both sheds light on how Outreach Projects are put into practice at PUCE, and emphasizes the need for teamwork. This project joined the efforts of two of PUCE's undergraduate programs and revitalized an agreement of allies who share the common cause of Social Justice. It is important to remark that this aspect also coincides with the Ecuadorian Constitutional Plan for Good Living (Senplades, S. N., 2013) as well. The project gave closure to the cycle of education, investigation, and community and resulted in an awareness of peaceful coexistence and mutual respect for every stakeholder involved in the process.

\section{THEORETICAL FRAMEWORK}

\section{What is the Systematization of an Experience?}

According to Jara (2012), Systematization of Experiences is a research method that adapts to conditions, possibilities, resources, and the characteristics of the experiences that a researcher wishes to systematize. The methodological challenges - even if they imply a search for technical tools - should be taken on based on the definition of criteria and methodological principles that allow an entire work "strategy" to be structured: planning, design, orderly execution, and coherent processes. This has an accumulative logical sequence and results in a qualitative transformation from the starting situation.

This statement implies a radical break with the trend to identify methodological procedures with techniques: in other words, the understanding of scien- tific methodology as an instrumental problem. The methodological questions used in Systematization of Experiences for educational programs are thus related to the need to integrate a vision to guide and drive the training and educational processes (Berdegué, J. et. al, 2007). The methodological procedure must deal with the criteria and principles that give unity and strategic coherence to all elements involved in a process. Within this methodological framework, every specific moment that unfolds throughout the steps or actions is driven by the experiences themselves.

That is a methodological proposal: an intentional proposal of the path to be traveled. On the one hand, it will make it possible to actively guide the process in a given direction; on the other hand, it must be open to what happens along the way in order to modify the 
course if necessary, to the extent that those who propose the path are also those who walkers.

In the case of systematization of experiences for education, the metho- dology proposes five stages that suggest a certain expected order. The five stages that every systematization process should contain are the following:

Figure 1: The Five Stages of the Systematization Cycle

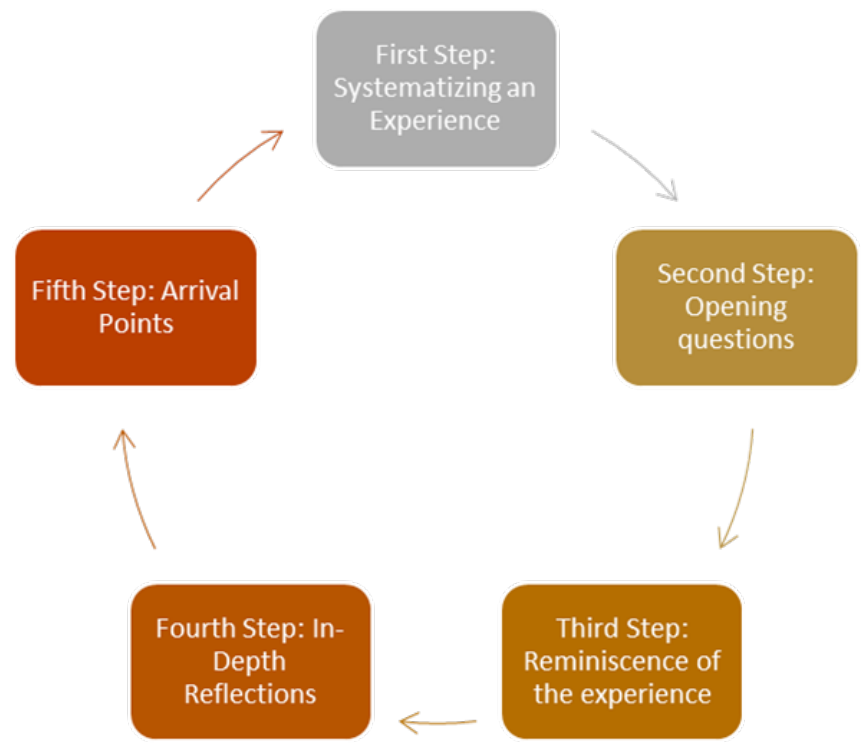

Source: Jara H. 0. (2012) La Sistematización de Experiencias: práctica y teoría para otros mundos posibles.

Elaborated by: Maritza Figueroa (2018)

What is Culture of Peace and Peace

\section{Education?}

The UNESCO defines Culture of Peace and Non-Violence as ". . . a commitment to peace-building, mediation, conflict prevention and resolution, peace education, education for non-violence, munity. tolerance, acceptance, mutual respect, intercultural and interfaith dialogue and reconciliation." (UNESCO, 2018). On the other hand, it defines Peace Education as the means by which this concept can be addressed within the educational com- 
According to the United Nations, a Culture of Peace is a series of values, attitudes, and behaviors that reject violence and prevent conflicts by identifying their causes, in order to solve problems through dialogue and negotiation between people, social groups and nations ( $\mathrm{R} \mathrm{A} / 52 / 13,1998)$; in other words, it rejects all form of violence and seeks that human relationships to be based on mutual respect, justice, solidarity and true equality (United Nations, 1998). This can be exemplified through the implementation of culture of peace workshops at Santa Teresita del Valle School.

In the case of Ecuador, a Culture of Peace is thus a fundamental element in poverty eradication. It is an essential part of national policies and regulations and is enshrined in Ecuador's Constitutional Plan for Good Living'. This national objective will be carried out by endorsing State-funded educational and communicative mechanisms to pursue social and cultural transformation and eradicate all forms of violence (gender, intergenerational, ethnic6/racial, an0d school bullying) (Subdirección Nacional de Centros de Mediación y Justicia de Paz, 2016)

In order to teach peace, one much teach "the skills and attitudes needed to listen with empathy; express our feelings and concerns in a respectful manner; see problems from the other person's point of view; be respectful of the diversity among us; work together cooperatively; and resolve conflict peacefully" (van Gurp, 2012). It is through this type of pedagogy that educators can demonstrate that there are alternatives to violence (van Gurp, 2012).

Peace Education, therefore, is a commitment to teach a Culture of Peace. Since this uses the ideas of mutual understanding, respect and assertive communication to view human beings - not as a focus of conflict, but as a beacon of peace - it is crucial that all stakeholders be involved in this process.

\section{METHODOLOGY}

\section{First Step: Systematizing an Experience}

This article is a systematization of the experience of conducting culture of peace workshops at the Santa Teresita del Valle School located in the Valle de los Chillos, Province of Pichincha, in Quito, Ecuador. The Outreach Department

\footnotetext{
${ }^{1}$ Plan Nacional del Buen Vivir, translated by the Authors.
} 
for the Pontifical Catholic University of Ecuador (PUCE) was contacted by the Jesuit Religious organization "Fe y Alegría" (Faith and Joy) because it needed assistance in order to comply with the Ecuadorian Judicial Council's require implementing a predetermined program that would reduce violence and promote a harmonious quality of life style within Ecuador's primary and secondary school system. The Multilingual School of International Business and International Relations (MSIBIR) was selected alongside the School of Social Work to meet the needs of PUCE's outreach department. This department designated Milica Dragosavljevich, outreach Tutor of the Multilingual School of International Business and International Relations, and Abel Crespo, the outreach Tutor of the Social Work School, to develop a logical framework approach project which would address the need for Fe y Alegría Schools.

Once the logical framework approach project was approved by PUCE administrators, both outreach Tutors from the schools mentioned visited the Santa Teresita del Valle School, which is part of the Fe y Alegría network; this school was open to the idea of having PUCE students visit and provide Culture of Peace workshops during school hours.
Before the official start of the process, the School Principal and School Psychologist informed the PUCE Tutors that the Ecuadorian Judicial Council ${ }^{2}$ had asked them to survey their Student and Parent Committee in order to diagnose the consciousness of violence within this social group. The PUCE Tutors found that the survey results were neither tabulated, nor had they been administered to the entire student body. They thus proceeded to tabulate and complete these surveys in order to plan the Culture of Peace workshops to be carried out by the PUCE Students. Following this, during a two-month period of consultation, the PUCE Tutors, in conjunction with the School Principal and the School Psychologist, agreed upon the main themes and methodological approaches to be used during the workshops in accordance with the professional skills present in the undergraduate programs of the Multilingual School of International Business and International Relations and the School of Social Work School. The schedule was set and approved by the School Principal. The PUCE Tutors then requested that the selected undergraduate students attend a briefing regarding the outreach program.

This was divided into two time periods: February $15^{\text {th }}$ to June $30^{\text {th }}$ as the

\footnotetext{
${ }^{2}$ Consejo de la Judicatura, translated by the Authors.
} 
first stage, and November $7^{\text {th }}$ to March $31^{\text {st }}$ as the second stage.

\section{First Stage: First Half of 2016}

The project began in February of 2016. Santa Teresita del Valle is a primary school located in a semi-rural area of Quito. It has approximately 330 students divided into seven grades, including kindergarten. There are 11 teachers in total, including the School Psychologist, who is also the English Teacher for certain grades. The parent committee is quite active: not only at the school, but also in supporting projects throughout the Santa Teresita community. The school is located approximately 14 kilometers (27 minutes by car, and 1 hour and 12 minutes in public transportation) from the PUCE main campus, located in the city center of Quito. In terms of infrastructure, the school has three buildings, two cemented soccer fields, and an interior patio where the main events are held. There is a small computer lab with 20 functional computers and an audiovisual room with a projector. All basic facilities are available to all school members, including the nurse's office.

For this particular project stage, each classroom had one PUCE student from Social Work and another from the Multilingual School of International Business and International Relations. Activities were carefully planned, based on the logical framework approach project, which has a problem-based strategy that enables the project developer to create activities to solve specific needs. The class planning matrix was thus specially designed to use not only the guidelines provided by the logical framework approach, but also entirety of language learning/teaching, as well as the UNESCO's Culture of Peace training methods.

Each pair of PUCE students (one from the School of Social Work and one from MSIBIR) designed their tasks based on a short workshop that the Outreach Tutors had given to them two weeks before the start of the workshops. Each classroom had approximately 20 students per class, although some upper grades had only 7 pupils. An online Dropbox account was created for the students to upload their planning two days before they presented their workshops, and access was given to the School Principal and School Psychologist. Once each pair of students had uploaded their class planning, a general review was carried out by the PUCE Outreach Tutors. If there were any comments on the part of the School itself, the School Psychologist or the School Principal would talk to the PUCE students directly after the workshop. It is important to mention that two PUCE students were given the task of creating Culture of Peace workshops for the school teachers, and two more PUCE 
students were likewise assigned to create weekend workshops for the parent committee.

As was mentioned, each pair of students would upload and fill out the class planning matrix on a weekly basis and await any feedback from the PUCE outreach tutors. In the event that there were comments from the tutors, these comments were given either through a Skype video call or face-to-face at the University during office hours, prior to the workshop. Modifications were made immediately following the outreach tutors'instructions. Once the class planning was agreed upon, any questions about methodologies or procedures were also clarified to the students.

The outreach program began with an inaugural event held at the School's main patio, where the PUCE tutors and students introduced themselves to one another. The PUCE students were referred to as "Aunties and Uncles." The School Principal and Psychologist opened the event with some words of appreciation for PUCE and expressed their contentment that the two institutions were working together for the same cause. The PUCE tutors, in turn, conveyed their gratitude to the Santa Teresita School. After this short event, the first workshop started on February 15 $5^{\text {th }}, 2016$.

According to the schedule, every Friday through June $30^{\text {th }}$, 2016 each stu- dent would have an hour commute to travel to the target School using public transportation. Students of the School of Social Work, who were very accustomed to community work, provided a positive example to the Students of MSIBIR, who were not experienced in engagement in outreach programs; this despite the fact that they were older than the Social Work Students (19 years old versus 22 years old, on average). Once they were at the School, teachers from each grade welcomed the PUCE Students and had the children welcome them as well. In this way, the children thus understood that the workshop had begun. It is important to note that, as stated before, the children would call the PUCE Students "aunties and uncles"; this created a distinction from the grade school teachers, and also gave the children the opportunity to feel that the PUCE students were approachable.

From 7:15 to 7:55am, student facilitators conducted the workshop using the classroom planning matrix and the recurring themes provided by the Culture of Peace curriculum. Each workshop session included: a warm up activity where students sang songs and/or performed total physical response (TPR) activities with the children, which prepared them for the tasks to follow; the general theme of the day was then introduced with core tasks which were usually writ- 
ten, read, or involving coloring or manual undertakings; finally, the session was wrapped up with either the same song or TPR activity done at the beginning. An alternative activity might be an expectation task to stimulate the children's curiosity about the next session.

On a monthly basis, both Outreach Tutors provided PUCE Students with feedback sessions in which comments and experiences were shared. The sessions with the School Teachers and Parent Committee were conducted in a similar manner but dealt with other aspects that had to be addressed in a different way. The PUCE Tutors provided on-going support for PUCE students and created a strong bond with the School Principal and Psychologist. One of the Tutors provided technical support for the school's computer laboratory, in order to ensure the proper functioning of the broadband internet.

For 16 weeks, the workshops were successfully conducted as planned. As a finale, an open house was planned together with the School Staff and the Parent Committee. Each grade created a culture of peace skit or dance to present at the open house. This activity's purpose was to demonstrate how the culture of peace workshops made a better world. The younger grades created paper cutouts with symbols of peace to place upon a large painted polystyrene foam globe which represented the Earth. Towards the end of the open house, the PUCE Tutors presented the statute of the mediation club to the School for the school to review and comment on. Two weeks later, the PUCE Tutors held a meeting with the School's Principal in order to evaluate the first period of workshops, and they decided to continue the project for a second period. The objective of the following period would be to implement the mediation club, continue with the regular workshops to reaffirm the impact of the first stage, and lastly, provide the school with mechanisms to maintain its own self-development in this area.

\section{Second Stage: Second Half of 2016 and First Months of 2017}

During the semester break, preparations were made with the MSIBIR students because the Social Work students had been assigned to other community projects. Consequently, during the last week of October, a Culture of Peace Training was carried out by Aracelly Villalobos, M.A. a volunteer of the Resettlement program at the office of the United Nations High Commissioner for Refugees (UNHCR) in Ecuador. She was pursuing a Master's Program at the time at the United Nations-mandated University for Peace in Costa Rica. The MSIBIR students greatly benefited from the information. Subsequently, students 
were informed how to proceed to plan the culture of peace workshops for the school and were presented with the predetermined program that the Ecuadorian Judicial Council had given to the school officials. Online tools were then set up in order to facilitate communication and storage of referential documents, including formats, schedules, and basic literature.

During the week of November $7^{\text {th }}$ to $11^{\text {th }}$, the workshops for this stage were inaugurated, with 24 PUCE Students divided into the different grades, from pre-kindergarten to $9^{\text {th }}$ grade, with 2 PUCE Students assigned per grade. In addition, two students were assigned the task of working with the school teachers. Each pair of students worked with the parents and/or care givers for each grade on designated Saturday mornings. This adjustment was proposed to the School Principal by the PUCE's outreach Tutor Milica Dragosavljevich, so as to enhance maximum participation and family involvement. The School Principal accepted the proposal and viewed it as beneficial in promoting care giver commitment to the School and the Culture of Peace.

The workshop schedules (7:15am - 7:55am), as well as classroom planning formats (Culture of Peace Curriculum) and implementation (warm up activity, core tasks and wrap up session), were replicated starting with the First Stage. Sessions with school teachers were conducted in a similar way. The monthly feedback sessions between the Outreach Tutors and the PUCE Students likewise took place. Finally, sessions with the Parent Committee were held on Saturdays, starting with an aerobic workout session given by one of the PUCE Students, who is a recognized Ecuadorian athlete. During this second stage, as mentioned before, each pair of PUCE students worked with the Parents/Care givers for their corresponding grade.

At this stage, workshops were successfully conducted for 18 weeks. Prior to the year-end holiday season, PUCE students organized a celebration for the children. On that day, the children made "peace" Christmas ornaments for the school's tree and one of the students dressed up as Santa Claus. The main objective was to promote the sentiment of peace that this time of year traditionally entails. At the end of the term, a closing session was planned with the School Staff and the Parents Committee.

The same results were not achieved in this term. Some PUCE students withdrew from the project because they had already participated in another university outreach activity. New students thus had to be integrated and there was insufficient time to fully instruct them regarding the workshop mechanism. 
This threw off the process, meaning that the objective of implementing the mediation club was not fully achieved due to the lack of commitment from PUCE students. Not all grades were affected by these changes, however, and the pair of students who worked with the school teachers were able to convey the importance of continuing activities of a culture of peace throughout the school year. In addition, each classroom had elected a custodian of peace who monitored class well-being, in order to follow-up with implementation of the mediation club.

To conclude this process, a group of PUCE students organized two focus groups with random students from grades 2, 4, 6 and 7 in June 2017, in order to measure the impact of having a custodian of peace in each grade and determine future implementation of the mediation club.

\section{Second Step: Opening Questions}

Object to be systematized: Which experience will be systematized?

Implementation process: Culture of Peace Program

Objective and Benefits to be Systematized: What is the purpose of systematizing this experience?

Objective: Develop a critical process that will enable a comprehension of the Culture of Peace workshops as part of the Ignatian Social Responsibility Network Experience.

Benefits: Record and promote the process of systematizing the experience of the Culture of Peace workshops.

Systematization Axis: Which aspects of the experience are of most interest?

Culture of Peace Training Workshop

\section{Sources of Information}

The sources of information that were used in order to systematize the experience are as follows:

a. Existing Documentation:

- Electronic Correspondence with PUCE Outreach Program Coordinator and School Principal.

- PUCE Student Activity Reports

- Survey Results from the Ecuadorian Judicial Council

- Culture of Peace Logical Framework Approach Project

- Tutor Final Report

- Videos and Pictures

b. New Documentation:

- Surveys adapted to the needs of the Fe y Alegría Network

- PUCE Student Activity Reports

- Individual Interviews with School Principal and Psychologist. 
- $70 \%$ Parent Focal Group

- 70\% Student Focal Group

- Tutor Final Report

\section{Product Description}

Culture of Peace Article

\section{Third Step: Reminiscence of the Experience}

List of significant moments found

\begin{tabular}{|c|c|c|c|c|}
\hline MAIN EVENTS & $\begin{array}{l}\text { MLLESTONES OFTHE } \\
\text { EXPERIENCE }\end{array}$ & STAGES & $\begin{array}{l}\text { CONTEXTUAL IMPAC- } \\
\text { TING ELEMENTS } \\
\end{array}$ & ACTOR \\
\hline $\begin{array}{l}\text { First visit to School: } \\
\text { Outreach program } \\
\text { coordinator visits } \\
\text { location in order to } \\
\text { obtain project proposal } \\
\text { approval from the PUCE } \\
\text { Outreach Department } \\
\text { by the PUCE tutors: } \\
\text { Crespo and Dragosavl- } \\
\text { jevich }\end{array}$ & $\begin{array}{l}\text { PUCE and Fe and Ale- } \\
\text { gría Network Chair join } \\
\text { to support outreach } \\
\text { programs }\end{array}$ & \multirow[t]{2}{*}{$\begin{array}{l}\text { First Stage: First half } \\
\text { of } 2016\end{array}$} & $\begin{array}{l}\text { The Ecuadorian Judicial } \\
\text { Councilasks Santa Tere- } \\
\text { sita to apply"Semilleros } \\
\text { de Convivencia" (Plan- } \\
\text { ting Peaceful Co-Exis- } \\
\text { tence Workshops) and } \\
\text { Fe and Alegría in turn } \\
\text { asks PuCE for reinforce- } \\
\text { ment with the Culture } \\
\text { of Peace workshops } \\
\text { which are tailored to } \\
\text { their needs. }\end{array}$ & $\begin{array}{l}\text { PUCE Outreach pro- } \\
\text { gram coordinator and } \\
\text { tutors visited School } \\
\text { Principal and Psycho- } \\
\text { logist }\end{array}$ \\
\hline $\begin{array}{l}\text { PUCE Outreach pro- } \\
\text { gram tutors evaluate } \\
\text { the situation of Santa } \\
\text { Teresita }\end{array}$ & $\begin{array}{l}\text { Outreach tutors ask } \\
\text { school to apply Consejo } \\
\text { de Judicatura's survey } \\
\text { to 100\% of their } \\
\text { students }\end{array}$ & & $\begin{array}{l}\text { Based on the Ecuado- } \\
\text { rian Judicial Councire- } \\
\text { quirements and Santa } \\
\text { Teresita School needs, } \\
\text { results were analyzed } \\
\text { and workshop themes } \\
\text { were developed } \\
\text { by PuCE tutors: Crespo } \\
\text { and Dragosavljevich }\end{array}$ & $\begin{array}{l}\text { PUCE tutors: Crespo } \\
\text { and Dragosavljevich } \\
\text { developed workshop } \\
\text { planning formats and } \\
\text { opened on line docu- } \\
\text { mentation storage and } \\
\text { communication system } \\
\text { (Google Drive) in } \\
\text { order to document and } \\
\text { systematize project's } \\
\text { underpinnings }\end{array}$ \\
\hline
\end{tabular}




\begin{tabular}{|c|c|c|c|}
\hline $\begin{array}{l}\text { The Schools of Social } \\
\text { Work and Multilingual } \\
\text { in IB and IR join efforts } \\
\text { to develop Culture of } \\
\text { Peace Workshops }\end{array}$ & $\begin{array}{l}\text { Both PUCE depart- } \\
\text { ments meet to plan } \\
\text { and organize instru- } \\
\text { ments and materials for } \\
\text { workshops. }\end{array}$ & $\begin{array}{l}\text { First time the depart- } \\
\text { ments of Social Work } \\
\text { and Multilingual of IB } \\
\text { and IR have worked } \\
\text { together on an ou- } \\
\text { treach project. }\end{array}$ & $\begin{array}{l}\text { PUCE Outreach pro- } \\
\text { gram tutors from the } \\
\text { departments of the } \\
\text { School of Social Work } \\
\text { and Multilingual of IB } \\
\text { and IR are introduced } \\
\text { to the project's formats } \\
\text { and communication } \\
\text { system and are urged } \\
\text { to work together on } \\
\text { workshop planning on } \\
\text { a weekly basis. }\end{array}$ \\
\hline $\begin{array}{l}\text { Inauguration of first } \\
\text { workshops. }\end{array}$ & $\begin{array}{l}\text { PUCE "Aunties and Un- } \\
\text { cles" are introduced to } \\
\text { Santa Teresita's students } \\
\text { and teacher body. }\end{array}$ & $\begin{array}{l}\text { The student and } \\
\text { teacher body of Santa } \\
\text { Teresita start off on the } \\
\text { right foot; a relations- } \\
\text { hip begins. }\end{array}$ & $\begin{array}{l}\text { PUCE Outreach } \\
\text { program tutors and } \\
\text { students from the } \\
\text { departments of the } \\
\text { School of Social Work } \\
\text { and Multilingual of IB } \\
\text { and IR as well as the } \\
\text { Santa Teresita student } \\
\text { and teacher body. }\end{array}$ \\
\hline $\begin{array}{l}\text { Saturday workshops for } \\
\text { Santa Teresita's parent } \\
\text { committee. }\end{array}$ & $\begin{array}{l}\text { PUCE students are } \\
\text { introduced to the } \\
\text { Santa Teresita parent } \\
\text { committee. }\end{array}$ & $\begin{array}{l}\text { Saturday workshops are } \\
\text { planned along with the } \\
\text { Santa Teresita teachers } \\
\text { and administrative } \\
\text { staff. School teachers } \\
\text { are given the opportu- } \\
\text { nity to apply what they } \\
\text { learned during their } \\
\text { workshop session with } \\
\text { PUCE students }\end{array}$ & $\begin{array}{l}\text { PUCE Outreach } \\
\text { program tutors and } \\
\text { students from the } \\
\text { departments of Social } \\
\text { Work and Multilingual } \\
\text { of IB and IR as well } \\
\text { as the Santa Teresita } \\
\text { parent committee and } \\
\text { teaching staff. }\end{array}$ \\
\hline
\end{tabular}




\begin{tabular}{|c|c|c|c|c|}
\hline $\begin{array}{l}\text { Open House: Mediation } \\
\text { Club statutes. }\end{array}$ & $\begin{array}{l}\text { An Open House was or- } \\
\text { ganized with the PUCE } \\
\text { tutors and students, } \\
\text { not only to comply } \\
\text { with the Ecuadorian Ju- } \\
\text { dicial Council's petition } \\
\text { to end the school } \\
\text { year's "Semilleros de } \\
\text { Convivencia," but also } \\
\text { to welcome parents } \\
\text { and neighbors to Santa } \\
\text { Teresita's declaration as } \\
\text { a"Territory of Peace." }\end{array}$ & & $\begin{array}{l}\text { The PUCE students } \\
\text { and Outreach tutors } \\
\text { officially presented the } \\
\text { Santa Teresita statutes } \\
\text { for a teacher-student } \\
\text { run Mediation Club. }\end{array}$ & $\begin{array}{l}\text { PUCE Outreach } \\
\text { program tutors and } \\
\text { students from the } \\
\text { departments of Social } \\
\text { Work and Multilingual } \\
\text { of IB and IR as well } \\
\text { as the Santa Teresita } \\
\text { parent committee and } \\
\text { teaching staff. }\end{array}$ \\
\hline $\begin{array}{l}\text { Officials from Fe and } \\
\text { Alegría Network } \\
\text { request a second set of } \\
\text { workshops. }\end{array}$ & $\begin{array}{l}\text { Fe y Alegría send the } \\
\text { Outreach program } \\
\text { department a thank } \\
\text { you letter and ask for a } \\
\text { second phase. }\end{array}$ & $\begin{array}{l}\text { Second Stage: } \\
\text { Second half of } 2016\end{array}$ & $\begin{array}{l}\text { The Multilingual Inter- } \\
\text { national business and } \\
\text { International Relations } \\
\text { Department takes over } \\
\text { the project and starts a } \\
\text { new cycle of workshops } \\
\text { to reinforce know-how } \\
\text { and start the Mediation } \\
\text { Club for the Santa } \\
\text { Teresita student and } \\
\text { teacher body as well as } \\
\text { the parent committee }\end{array}$ & $\begin{array}{l}\text { PUCE Outreach } \\
\text { program tutors and } \\
\text { students from the } \\
\text { Multilingual Depart- } \\
\text { ment of IB and IR and } \\
\text { the Santa Teresita and } \\
\text { teaching staff. }\end{array}$ \\
\hline Christmas Workshop & $\begin{array}{l}\text { The Multilingual Inter- } \\
\text { national Business and } \\
\text { International Relations } \\
\text { Department students } \\
\text { organize a Christmas } \\
\text { workshop. }\end{array}$ & & $\begin{array}{l}\text { PUCE students donate } \\
\text { candy bags and a tree } \\
\text { to the school. }\end{array}$ & $\begin{array}{l}\text { Students from the } \\
\text { Multilingual Interna- } \\
\text { tional Business and } \\
\text { International Relations } \\
\text { Department. }\end{array}$ \\
\hline
\end{tabular}


SYSTEMATIZING A CULTURE OF PEACE IN THE SANTA TERESITA DEL VALLE SCHOOL, QUITO - ECUADOR

\begin{tabular}{|c|c|c|c|}
\hline $\begin{array}{l}\text { Closing and Systema- } \\
\text { tizing Experience }\end{array}$ & $\begin{array}{l}\text { The Multilingual } \\
\text { Department of IB and } \\
\text { IR in-coming and out- } \\
\text { going outreach tutors } \\
\text { beign to systematize } \\
\text { the experience in order } \\
\text { to document it in the } \\
\text { form of an article. }\end{array}$ & $\begin{array}{l}\text { Together with the } \\
\text { Investigation Depart- } \\
\text { ment, the PUCE's Ou- } \\
\text { treach program Depart- } \\
\text { ment has in-coming } \\
\text { and out-going tutors } \\
\text { develop an article using } \\
\text { a methodology called } \\
\text { "Systematization of } \\
\text { Experiences." }\end{array}$ & $\begin{array}{l}\text { The Multilingual } \\
\text { Department of IB and } \\
\text { IR in-coming and out- } \\
\text { going outreach tutors } \\
\text { are Maritza Figueroa } \\
\text { and Milica Dragosavlje- } \\
\text { vich, with the support } \\
\text { of Outreach tutor Abel } \\
\text { Crespo. }\end{array}$ \\
\hline
\end{tabular}

Elaborated by: Abel Crespo and Milica Dragosavljevich (2017)

\section{Fourth Step: In-Depth Reflections}

Critical Interpretation: Why have these diverse stages been experienced?

The following stages took place due to a variety of factors that will be analyzed in the following paragraphs.

During the first stage, Fe y Alegría takes part in the same fundamental objectives that promote social equality and justice for Ecuador's most vulnerable population. Thus, the first event consisted of an initial visit that was the product of social networking by the PUCE with other institutions. Both institutions promote education as the principal tool to be used towards the millennium goal of poverty reduction.

At the same time, through the national plan of good living the Ecuadorian government has been promoting a secure and safe environment for all citi- zens; one of these environments was the goal of an educational project endorsed by the Ecuadorian Judicial Council called, as explained earlier, "semilleros de convivencia".

As a result, these three actors (PUCE, Fe y Alegría and the Ecuadorian Judicial Council) came together in an outreach program whose purpose was not only fulfill each institution's strategic plans, but also to have a meaningful effect on the community of Santa Teresita through culture of peace workshops. The interactive workshops were created and implemented by PUCE students and tutors and were specially designed to meet the need of students, teachers and parents to coexist harmoniously.

This first stage was very successful because it merged two academic know-hows: namely the School of Social 
Work and the Multilingual School of International Business and International Relations (MSIBIR). This sum of individual know-hows resulted in a robust program in which the technical multilingual and multicultural mindset of the MSIBIR students came together with the approach of the Social Work students to engage on a personal level with the community. Consequently, the PUCE students generated ownership and leadership for the project, which resulted in Fe y Alegría's request for continuation with another phase in order to provide continuity.

During the second stage, the Social Work students could no longer be part of the project, and the MSIBIR students had already graduated; therefore, new, younger-generation students were recruited from the latter school.

\section{Fifth Step: Arrival Points}

One of the aspects that generated a new perspective and created value for project execution was interdepartmental cooperation; namely, the School of Social Work and the Multilingual School of International Business and International Relations (MSIBIR). The conjoined effort of these two schools provided an interdisciplinary work methodology which enhanced a work method that combined two know-hows: social justice interaction and multicultural savoir faire. As reported during the stakeholder in- terviews, the social actors had a sense of wholeness and consequently their need was fulfilled.

Nevertheless, the School of Social Work could not participate during the second phase. This produced a gap in the work method which impacted the outcome. The MSIBIR students were unable to add social justice interaction to their workshop planning and accomplish the goal of starting the Mediation Club at the school. It is important to mention that the first group of MSIBIR students was no longer available, as they had already graduated. The second group recruited had already fulfilled a percentage of their community service hours and were not fully engaged; as a result, they were not committed to the community and did not participate in the project to the best of their abilities.

According to a survey of the Santa Teresita teachers immediately following the workshops, 60\% fully agreed and $40 \%$ agreed that the project generated a visible change. This result indicates that actors who are exposed on a daily basis to possible direct sources of conflict (student and parent body) could note a difference in their behavior and the use of alternative conflict resolution.

Another source of information was the results obtained during the questioning of focus groups conducted by MSIBIR students (Informe Grupos Fo- 
cales, 2017). A sample group of second, fourth, sixth, and seventh graders was randomly selected to participate in a circular focus group where students responded to the following questions:

1. Do you like to go to school? Yes, No. Why?

2. Which culture of peace activity do you most remember?

3. Do you know what it means to be in conflict?

4. Do you know how to negotiate to solve a problem?

5. If you see two classmates fighting, do you get involved? How do you get involved? Why yes? Why no?

6. Do you think that the culture of peace workshops helped you in some way? How so?

7. Who is the "custodian of peace" in your classroom?

8. Do you think it is a good idea to have a "custodian of peace" in your classroom?

9. Has the "custodian of peace" been useful?

While answers varied, the following sample reactions can be stated using the examples below:

"I like to go to school because I can play and make new friends; we can learn new and interesting things."

\section{"You shouldn't hit anyone."}

Regarding the concept and the function of peace-keepers, children were not clear on how they operate within the classroom because some of them"joined in the mischief, didn't know how to act in front of classmates, and froze up."

Santa Teresita students had a clear picture of the purpose of the culture of peace workshops and how "violence is bad" within as well as outside of the classroom.

In addition, approximately a year after the last workshop was carried out, the School Principal and Psychologist were interviewed. The following questions were asked:

\section{Before Initial Stage}

- What actions were taken in the event of a conflict between the parent and teaching committees and/ or students before the workshops took place?

\section{Intervention Process}

- Please tell us about the important activities that were organized by the PUCE during the Culture of Peace Project.

\section{Final Stage}

- Could you please tell us how the stakeholders (students, parents and 
teaching committees) acted and reacted during a recent conflict?

- Do you consider that they reacted differently after having participated in the culture of peace workshops?

\section{Lessons Learned}

- If you were able to change any aspect of the project, what would it be?

- How would you do things differently? Why?

The results of the interviews were as follows:

For the first question, the School Principal replied that she would first listen attentively to both parties involved and initiated a dialogue in order to arrive at an agreement. Then, she would review what the Ecuadorian Educational Bylaws stated about the matter and proceed to intervene.

On the other hand, the School Psychologist responded: "from a popular educational philosophical perspective, on which our institution is pedagogically based, we have sought to mediate conflictive situations through dialogue. Parents, students, and teachers arrived to agreements and settlements in order to avoid conflict."

For the intervention process, the School Principal responded that an outstanding characteristic was the outreach process created by PUCE, which is focused on each stakeholder group (students, parents, and teachers) in particular. FinaIly, she added that PUCE had fulfilled the established timetable and roles. In addition, PUCE also attended to the needs of the other organizations involved in the project. During the intervention process, there was an open space for dialogue in order to provide immediate solutions to any given situation within the project. Finally, the Principal said that, despite the PUCE students' inexperience in handling groups of children, the outcome was satisfactory on both ends, as they learned how to quickly confront and deal with unexpected situations.

The School Psychologist stated that it was important to point out that PUCE students achieved a sense of empathy that modified aggressive behavior observed within the school. She also explained that a Mediation Club was established in which the school children learned how to respect personal space and arrived at agreements, while being assertive and empathic. Each year, the elected student council was in charge of the process.

In the final stage, the School Principal noted that conflict resolution processes were employed. She added that prior the workshops, in the case of conflicts between students or parents the matter would be discussed off of 
school grounds. This resulted in an unfavorable conflict between adults. Following the culture of peace workshops, students approach their teachers if they feel unable to handle a problem on their own. The School Principal likewise noted that the culture of peace processes are followed, including dialogue and mutual agreements.

The School Psychologist stated that when addressing situations of conflict, the stakeholders have notably changed their conduct during the three years since the Ecuadorian Judicial Council first proposed the project to public, mixed, and municipal schools. There have been no significant conflicts between students, dialogue is used, and parents are respectful. Nevertheless, in the case of new students and their parents, these precepts need to be clarified.

When asked if the stakeholders acted differently following the culture of peace workshops, the Principal confirmed that attitudes have indeed changed to favor interpersonal relationships. The School Psychologist, on the other hand, noted that the concept of violence is clear to stakeholders and they are aware of how to prevent it. There is thus an evident change in how conflict is dealt with, above all in family matters. On school grounds, the Psychologist has observed that children can identify aggression and know how to avoid it, although it has not been eliminated.

As far as lessons learned, the School Principal pointed out that since the three participating parties (Fe $y$ Alegría, PUCE, the Ecuadorian Judicial Council) co-authored the development of culture of processes, objectives were fulfilled. She furthermore stated that the project should maintain the same schemata with the tutoring procedure that originated it. The School Psychologist remarked that since all activities were tailored to each grade's needs in order to make them dynamic and participatory, there would not be any need for change.

\section{CONCLUSION AND RECOMMENDATIONS}

The Systematization of Experiences methodology was both challenging and a meaningful mechanism for implementing Culture of Peace education. It created a space for reflection for the outreach program at PUCE and an unders- tanding of how project stakeholders play an important role in achieving the goal of good living. The challenge of collecting and recalling experiences called for a new approach to research and demanded a strict organization of documentary 
evidence at every stage of the process. The meaningful aspect becomes a conjoined effort of community service, education, and investigation; a cycle that is not always closed. Consequently, Fe y Alegría, the Ecuadorian Judicial Council, PUCE, and Santa Teresita del Valle School are pioneers in being part of the Culture of Peace Education and the Systematization of Experiences methodology cycle of educational research.

After analysis and evaluation of this experience, there are two aspects that should be noted for future reference. The first is that it is crucial to work in a community team without losing sight of one of the main focuses of an educatio- nal institution: research. This, in conjunction with dealing with, on the one hand, college education, and on the other, primary school education, gives community work a profound perspective that students need in order to develop a sense of being, whether on a professional or a basic level. Secondly, use of the Systematization of Experiences methodology allowed for a complete project analysis and evaluation that other traditional scientific methodologies could not have achieved. The analysis at every stage provided a holistic outlook on the results of both culture of peace education, and PUCE's community outreach programs. 


\section{REFERENCES}

Beltrán, I. (2018, January, 25). Interview type [email with Dragosavljevich, M. \& Figueroa, M].

Berdegué, J. et. al (2007). Sistematización de Experiencias Locales de Desarrollo Rural: Guía Metodológica. Fondo Internacional para el Desarrollo Agrícola FIDA, FIDAMERICA Y PREVAL.

Cárdenas, M. (2018, January, 24). Interview type [email with Dragosavljevich, M. \& Figueroa, M]

Jara H. O. (2012). La Sistematización de Experiencias: práctica y teoría para otros mundos posibles. CEP - Centro de Estudios y Publicaciones - ALFORA y CEAAL - Consejo de Educación de Adultos para América Latina. 1era ed. San José, Costa Rica.

Escuela Multilingüe de Negocios y Relaciones Internacionales, PUCE (2017). Informe Grupos Focales (Reporte No. 1). Quito: Pontificia Universidad Católica del Ecuador.

Escuela Multilingüe de Negocios y Relaciones Internacionales, PUCE (2018). Plan De Entrevista en Profundidad. Quito: Pontificia Universidad Católica del Ecuador.

PUCE. (2016). Apender a apender en la PUCE "Un modelo educativo para una Nueva Universidad" El Para- digma Pedagógico Ignaciano: Obtenido de http://www.puce. edu.ec/documentos/Aprender_a_aprender_en_la_PUCE. pdf

Senplades, S. N. (2013). Plan Nacional del Buen Vivir. Retrieved from http:// www.buenvivir.gob.ec/.

Subdirección Nacional de Centros de Mediación y Justicia de Paz. (Noviembre de 2016). Manual para la Implementación de la Guía de Formación de Semilleros de Convivencia con Docentes de Educación General Básica y Bachillerato General Unificado, y Personal de los Departamentos de Consejería Estudiantil (Dece). Quito, Pichincha, Ecuador.

The office of the United Nations High Commissioner for Refugees (UNHCR),(n.d). History of UNHCR. Retrieve from: http://www.unhcr. org/history-of-unhcr.html on October 13, 2017.

The United Nations-mandated University for Peace (UPEACE), ),(n.d). UPEACE. Retrieve from: https:// www.upeace.org/about-upeace on October 13, 2017.

UNESCO. (9 de Febrero de 2018). Culture of Peace and Non Violence. Recuperado el 9 de febrero de 2018, 
de Culture of Peace and Non Violence: https://en.unesco.org/ cultureofpeace/

United Nations. (10 de November de 1998). International Decade for a Culture of Peace and Non- Violence. Obtenido de UN documents: Gathering a body of global documents: http://www. un-documents.net/a53r25.htm

Van Gurp, H. (2012). Creating a Culture of Peace: A Pratical Guide for Schools. Obtenido de Peaceful Schools International : www.peacefulschoolsinternational.org 
SYSTEMATIZING A CULTURE OF PEACE IN THE SANTA TERESITA DEL VALLE SCHOOL, ||||| QUITO - ECUADOR 